\title{
Groundwater protection in shale gas exploration areas - a Polish perspective
}

\author{
Department of Geology, University of Warsaw, 02-089 Warsaw, Zwirki i Wigury 93, Poland. E-mail: ewa.krogulec@uw.edu.pl
}

(Received March 1, 2014: Revised accepted December 7, 2014)

A necessary element during unconventional gas exploration is the identification of possible environmental hazards. These hazards require quantitative and qualitative assessment to ensure groundwater protection. This is realized using legal-administrative and technical tools. In shale gas exploration areas, the most important method of groundwater protection is groundwater monitoring. Correct design of a monitoring system is based on studies allowing for early recognition of the real impact on groundwater. An optimally operating monitoring network should allow explicit determination of the direction, range and area of water pollution during shale gas exploration. In Poland and other countries, the existing solutions and legal regulations related to water monitoring are generalized and usually not specifically dedicated to assessment of hazard caused by shale gas exploration. There is a need for an individual approach to the concept and design of the monitoring network for each specific investment.

\section{Introduction}

Shale gas exploration in Poland causes many emotional reactions related to environmental aspects. Deep drilling with horizontal elements and processes of hydraulic fracturing require precise answers on the potential environmental impact. Lack of experience with application of hydraulic fracturing in shale gas exploration, despite the use of the technique in conventional reservoir stimulation, is accompanied by limited knowledge of facts related to environmental protection.

The situation is not improved by worldwide, 'anti-shale gas' propaganda, often not supported by evidence of actual, determined or potential hazards for the natural environment. Comments typically point to water pollution. Therefore it is vital to identify the possible impact of shale gas production on groundwater condition and quality. Experience with identification of hazards related to the present stage of exploration and plan for shale gas production in Poland is based on multi-annual hydrogeological monitoring studies.

A necessary element of studies in shale gas exploration should be the identification of possible environmental hazards in terms of their character and impact time. Potential results of environmental impact assessment should refer to the real cause and indicate the direct and indirect negative influences.

Results of studies in Poland, based on a wide range of regional and local groundwater monitoring studies are an important contribution to the discussion on the possible impact of shale gas exploration both in Poland and worldwide. Although high hopes are held by potential investors and exploiters for European shale gas resources, production may be restricted due to the resistance of inhabitants and politicians.

\section{Exploration, recognition and production of hydrocarbon resources in Poland}

The influence of shale gas exploration, recognition and production on groundwater is largely connected with the drilling process which is similar in impact on the hydrogeological environment to deep drilling for conventional hydrocarbons. The basic technological difference is the application of hydraulic fracturing using specific fluids. The fracturing fluid is a type of a drilling fluid applied in the drilling process to open or enlarge fractures in the shale gas rock. Both the classical drilling fluid and the fracturing fluid contain chemicals that result in their specific, essential properties. Each added chemical has an explicit function. Drilling fluids contain similar components to the fracturing fluid and are applied without reservations worldwide, including Poland, not only in shale gas drilling but also in conventional drilling for gas, crude oil or geothermal water. Poland has extensive experience in deep drilling and a long history of exploration and production of energy resources.

\section{Conventional hydrocarbons - Polish history}

The history of hydrocarbon production in Poland is one of the longest in Europe. Drilling for exploration and production of crude oil and gas have been undertaken for over 120 years, therefore our experience is significant. The 160-year jubilee of the Polish oil industry was in 2013. The beginnings date back to 1853 when Ignacy fukasiewicz made available the first kerosene lamp to a local hospital in Lviv to illuminate an emergency operation. The origin of the oil industry in south-eastern Poland commenced with mines called "dug holes", wells and hand-dug wells (Lipiñska, 2010). In 1860, one of the first wells was drilled: the "Franek" well in Bóbrka, which is still yielding oil. Over 60 wells were drilled between 1854-61; the deepest reached about $150 \mathrm{~m}$. Analysis of archival documents allowed 
the identification of 79 sites with natural seeps of crude oil prior to 1854. Some hand-dug wells are located within households or in sites, where crude oil is also exploited presently by the inhabitants (Lipiñska, 2010). One of the richest crude oil reservoirs in Eastern Galicia was discovered in 1896 at the depth of about $1000 \mathrm{~m}$. Summing up the Polish experience in exploration and production drilling for crude oil and natural gas, it should be stressed that so far over 7000 wells deeper than $1000 \mathrm{~m}$ have been drilled. According to records for the end of 2009, there are 49 gas mining areas and 24 crude oil mining areas. Natural gas production in Poland was 4.3 billion $\mathrm{m}^{3}$ in 2012 against a consumption of 15.8 billion $\mathrm{m}^{3}$ (Fig. 1). Crude oil production rose by 22\% in 2012, reaching 754 thousand tones (Górecki, 2003; Energy Policy of Poland 2009; Zagórski, 2013).

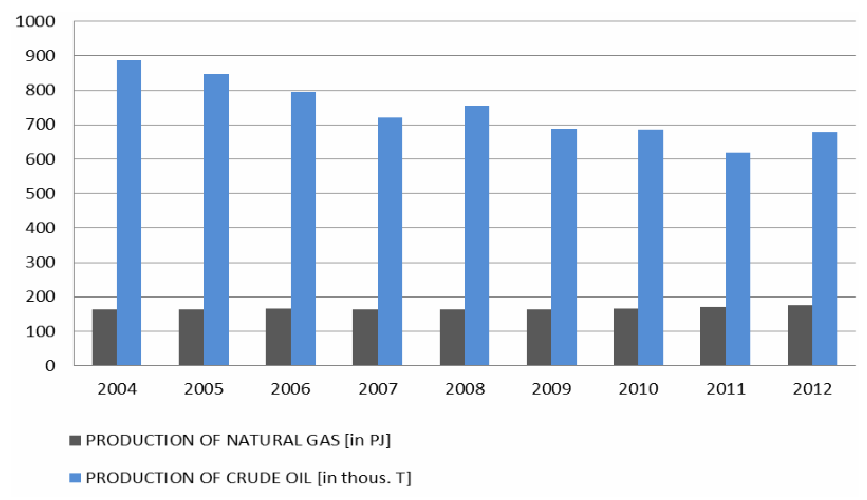

Figure 1. Production of natural gas and crude oil in Poland (source: http://www.stat.gov.pl/gus/5840_11289_PLK_HTML.htm).

So far, production for conventional hydrocarbons in Poland has not caused any problems with groundwater pollution. Incidents linked with device malfunctions and drilling activities have not resulted in groundwater pollution, local protests and or concern from administrators or regulators. Despite this long history of hydrocarbon production, no negative influence on human health has been observed.

\section{Unconventional hydrocarbons - gas and crude oil from shale formations}

Shale gas exploration began in Poland in 2007-2008. Shale gas exploration wells were made to confirm the geological structure and presence of the expected reserves or to conduct experimental treatments. These prospective wells were aimed at recognizing the type, magnitude and extent of the structure. Core was recovered in order to evaluate the rock reservoir properties, saturation with reservoir fluids, the magnitude of production and its economic value. Operations aimed at making the reservoir available, e.g. hydraulic fracturing have also been conducted in the wells. These processes require obtaining a concession for exploration and recognition of the reservoir. In August 2011, on the Lubocino-1 well, Polish Oil and Gas Company (PGNiG S.A.) carried out the first operation of hydraulic fracturing at a depth interval $2894-2907 \mathrm{~m}$. The total depth of this well is $3050 \mathrm{~m}$. Paleozoic rocks with a total thickness exceeding $2250 \mathrm{~m}$, are comprised of: Cambrian sandstones and siltstones, calcareous claystones, sandstones with glauconite, and claystones; Ordovician marly claystones and limestones (thickness 62,5 m); Silurian claystones and siltstones (thickness $1906 \mathrm{~m}$ ); and Permian (Zechstein) shales, dolomites, anhydrites and salts (thickness $281 \mathrm{~m}$ ).

By the end of April 2013, in Poland, 56 shale gas exploration
Table 1. Total drilling for shale gas exploration (as of 06/05/2014) (http:// www.lupkipolskie.pl)

\begin{tabular}{|l|c|c|c|}
\hline $\begin{array}{c}\text { The type of treatment } \\
\text { performed in the } \\
\text { borehole }\end{array}$ & $\begin{array}{c}\text { Number of } \\
\text { vertical } \\
\text { boreholes }\end{array}$ & $\begin{array}{c}\text { Number of } \\
\text { directional wells } \\
\text { (horizontal) }\end{array}$ & $\begin{array}{c}\text { Wells - } \\
\text { in total }\end{array}$ \\
\hline Fracture & 13 & 8 & 21 \\
Microfracture/DFIT* & 4 & 0 & 4 \\
No fracture & 27 & 4 & 31 \\
Together & 44 & 12 & 56 \\
\hline
\end{tabular}

wells were either completed or in progress, including 12 horizontal drillings (Table 1). The scheduled development of shale gas exploration and production in Poland depends not only on the evaluated reserves but also on the economic, political and social conditions in the country and in Europe (EIA, 2011; Assessment of Shale Gas..., 2012; Gautier et al., 2012; Johnson, Boersma, 2013; Kiersznowski, Dyrka, 2013).

Multiple scenarios with different pathways are discussed here. A scenario of moderate increase is treated as the practical achievable minimum without any significant new enterprises engaged in shale gas exploration and without significant exploration success, and with no relaxation of management conditions (social, economic). This scenario assumes 65 new exploration wells in 2012-2018 and 155 wells in 2019-2025 as well as 30 production wells in 2012-2018 and 270 in 2019-2025 (Energy Policy of Poland 2009).

The Ministry of the Environment has granted concessions for shale gas exploration in Poland to the largest Polish and international oil companies (Koziel, 2010; Pliszczyñska, 2013). As of 1 February 2014 , a total of 93 shale gas exploration concessions had been granted (http://gazlupkowy.pl/).

\section{Identification of potential hazards posed on groundwater in regions of shale gas exploration}

The shale gas reservoir is made available during explorationexploitation activities through treatments to stimulate production, e.g. hydraulic fracturing. The exploration activities in Poland require production stimulation but the number of fracturing treatments are much fewer than the number of treatments conducted in subsequent production of the reservoir.

In vertical drilling, hydraulic fracturing treatments are referred to as medium-scale fracturing. They require the application of c. 500 $\mathrm{m}^{3}$ of a low viscosity working fluid. Table 2 presents the parameters of a technological fluid for hydraulic fracturing in a vertical well in shales.

An active internet platform shows the composition of the fracturing fluids used in Europe. The webpage http://www.ngsfacts. org/findawell/list/ supplies data for only 6 drilling operations undertaken in Poland. In the U.S. there is a Federal internet platform FrackFocus (http://fracfocus.org/) with data on each drilling operation and its fracturing fluid.

Hazards posed to groundwater from shale gas exploration, exploration and production include (Ground Water Protection Council (GWPC, 2009); AEA, 2012; Sakmar, 2012; Vengosha et al, 2013; Jenner and Lamadrid, 2013; Jackson et al, 2013):

- Excessive water removal from groundwater intakes; 
Table 2. An example of the process liquid for the treatment of hydraulic fracturing in shale plays (i.a. http://fracfocus.org/chemical-use/ what-chemicals-are-used)

\begin{tabular}{|l|l|c|c|c|c|c|}
\hline Component & Drill & Volume $/ \mathrm{m}^{3}$ & $\begin{array}{c}\text { Volume of } \\
\text { total }\end{array}$ & Drill & $\begin{array}{c}\text { Volume } / \mathrm{m}^{3} \\
\text { Number of } \\
\text { total }\end{array}$ \\
\hline Water & $\begin{array}{l}\text { Horizontal drilling, } \\
\text { multistage fracturing }\end{array}$ & - & $20100 \mathrm{~m}^{3}$ & $\begin{array}{c}\text { Vertical drilling, } \\
\text { one stage fracturing }\end{array}$ & - & $520 \mathrm{~m}^{3}$ \\
\hline Biocide & & $0,02 \mathrm{~kg} / \mathrm{m}^{3}$ & $400 \mathrm{~kg}$ & & $0,02 \mathrm{~kg} / \mathrm{m}^{3}$ & $10 \mathrm{~kg}$ \\
\hline Natural polymer & & $1,5 \mathrm{~kg} / \mathrm{m}^{3}$ & $30000 \mathrm{~kg}$ & & $1,5 \mathrm{~kg} / \mathrm{m}^{3}$ & $750 \mathrm{~kg}$ \\
\hline Surface active agents & & $61 / \mathrm{m}^{3}$ & 1200001 & & $61 / \mathrm{m}^{3}$ & 30001 \\
\hline Fluxing agent & & $0,3 \mathrm{~kg} / \mathrm{m}^{3}$ & $6000 \mathrm{~kg}$ & & $0,3 \mathrm{~kg} / \mathrm{m}^{3}$ & $150 \mathrm{~kg}$ \\
\hline Hydrochloric acid 34\% & & $2641 / \mathrm{m}^{3}$ & 264001 & & $2641 / \mathrm{m}^{3}$ & 52801 \\
\hline Tertiary amine & & $51 / \mathrm{m}^{3}$ & 5001 & & $51 / \mathrm{m}^{3}$ & 1001 \\
\hline
\end{tabular}

- Disordered hydrogeological equilibrium caused by insufficient isolation of the drilled aquifer horizons, particularly of usable waters;

- Groundwater pollution caused by accidental introduction of effluents, polluted liquids from reservoirs of technological fluids or migration of pollution spills within the drilling rig;

- Groundwater pollution by fluids used in hydraulic fracturing, flowback fluids or reservoir waters due to their migration into the massif.

Application of water in the drilling process, including that used in hydraulic fracturing, is referred to as special water usage in the Polish Water Law (http://isap.sejm.gov.pl/DetailsServlet?id=WDU 20011151229). The Law requires a legal permit to be obtained for special water usage. In the case of drilling, the competent body issue a legal water permit is the district head. The permit is issued for a certain duration based on a legal water report, i.e. a document that presents the possibilities of water usage based on reservoir balance, analysis of water uptake by other parties in the neighborhood and many other aspects. The permit may be withdrawn or restricted without any compensation if, for example, the consumer has changed the purpose and range of water usage or the devices have been used inconsistently with the provisions of the permit, the water resources have naturally decreased, or regulations have changed. Groundwater is used in drilling activities and for all treatments on the drilling rigs, after obtaining relevant permits, in quantities depending on the type of drilling, its depth and other treatments within the rig. Concern related to excessive water consumption during shale gas exploration is groundless because the determined reserves available for management in Poland reach 13,626 million $\mathrm{m}^{3} /$ year which, with the presently registered level of groundwater consumption at 1,585 million $\mathrm{m}^{3} /$ year, gives the reserve of about $90 \%$ of the resources (Diagnosis of the current.., 2010). Water resources should be determined for specific exploration areas. In areas with a limited number of drilling operations, water deficiencies have not been observed and water resources are larger than water consumption.

A crucial aspect of these studies is the permanent control of usable water quantity and the analysis of local hydrogeological conditions with regard to the determined resources, which includes also water requirements of areas subject to environmental protection such as wetlands and Natura 2000 areas (Uliasz-Misiak and Winid, 2012).

Water recycling, i.e. usage of the flow-back fluid after treatment for repeated hydraulic fracturing, is also an important issue (Mantell, 2011). For the vertical drilling of Lubocino- 1 well, with the depth of
$3050 \mathrm{~m}$ (northern Poland), in which fracturing was conducted in 2011, modeling of hydrogeochemical behaviors was undertaken. This focused on matters such as the preparation of simulation models showing potential mixing of the fracturing fluid and the flow-back fluid with usable groundwater. Model analysis was conducted for different scenarios, e.g. to obtain a mixture with parameters allowing repeated effective usage in the subsequent fracturing processes. Hydrogeochemical models used PHREEQC software (Parkhurst and Appelo, 1999) as well as software prepared by the U.S. Department of Energy Water Mixing and Scale Affinity Model (ALL Consulting..., 2010). Technological procedures improving selected parameters of the flow-back fluid (initial cleansing) were omitted from the theoretical speculations and it was assumed that the flow-back fluid with a known chemical composition is the base (basal fluid) of the fracturing fluid obtained in the recycling process, whereas groundwater from the nearby source is the secondary component of the mixture. Modeling studies were focused on determining optimal proportions of the components to acquire a mixture with a composition most similar to the actual fracturing fluid with a known chemical composition, e.g. by selecting the value of conductivity as the matching indicator of the chemical composition of the resulting mixture (theoretical solution) in relation to the chemical composition of the fracturing fluid (actual solution). The simulated value of conductivity of the theoretical solution corresponds to the actual conductivity of the fracturing fluid at over $33.65 \%$ contribution of the flow-back fluid in the mixture. Mixing of $66.45 \%$ of groundwater and $33.65 \%$ of the flow-back fluid will result in a solution that even without procedures of initial cleansing will have a chemical composition similar to the basal fracturing fluid (Krogulec and Sawicka, 2012). Taking into account a c. 20-40\% reception of the flow-back fluid and considering its precisely determined amount e.g. in the £ebieñ drilling at $3455 \mathrm{~m}^{3}$ (Environmental Aspects of..., 2011), the evaluated amount of the flow-back fluid required for repeated fracturing with retention of the given proportions reaches from 235 to $470 \mathrm{~m}^{3}$ (Krogulec and Sawicka, 2012).

The largest hazard for groundwater quality is the inflow of fracturing fluids and flow-back fluids or methane from deeper structures into usable aquifer horizons. Chemical components of the fracturing fluid could cause a direct hazard to human health after infiltrating to potable water (Hammerand van Briesen, 2012; Alvarez et al, 2012; AEA, 2012). Moreover, other toxic substances may be formed due to complex biogeochemical reactions in the reservoir waters with the chemical components used in the fracturing fluid. Often due to significant changes of temperature and pressure 
conditions in the drilling and in the area surrounding the drilling rig, the mixture resulting from the mutual influence of particular chemical components may be very variable and should be assessed individually for each case.

It should be stressed that groundwater pollution in the usable aquifer horizon caused by influence of the operation is potentially possible only in the case of malfunctions within the drilling activities. In the case of correctly conducted and protected drilling, isolation of the aquifer horizons, free flow and mixing of technological fluids used in the fracturing procedures and production with usable pollution of groundwater is not possible (USEPA 2010, 2011, 2012; Rahm and Riha, 2012).

Groundwater pollution caused by emergency inflow of effluents, polluted fluids from reservoirs for operational liquids or migration of pollutants spilled within the drilling rig should also be discussed in terms of the time of potential pollutant migration in the vertical profile. A time taken for vertical migration of water in areas with large thicknesses of low permeability deposits is an effective protection against the penetration of pollutants from the surface, and is long enough to undertake repair measures and to dispose of potential pollutants. Analysis of the hazard posed to groundwater quality should include study of groundwater susceptibility to pollution in a given area (Eaton, 2013).

\section{Groundwater protection in regions of shale gas exploration - Polish solutions}

Groundwater protection is a set of measures and restrictions in the management of an area that guarantee constant good quality groundwater uptake in amounts not exceeding the calculated available resources of reservoir waters (regional scale) and production resources in water intakes (local scale). Groundwater protection is realized using legal and administrative as well as technical measures.

\section{Passive protection - examples of regulations applied in Poland}

Measures of passive groundwater protection are mostly linked with application of existing legal and administrative provisions, including: (1) determination of protective zones (for intakes and Main Groundwater Reservoirs) and establishment of interdictions and restrictions for carrying out various operations within their boundaries; (2) designing and introducing observation-controlling networks allowing for constant monitoring of groundwater quality and quantity within the influence of potentially hazardous sites; (3) control under current legal acts relating to environmental protection as well as analysis and evaluation of the condition of the environment, including assessment of environmental impact, especially in protected areas (with particular consideration of Natura 2000 areas).

The Inspectorate for Environmental Protection is an organization established for control and evaluation of environmental conditions. Acting in line with strictly determined procedures, the voivodeship (province) inspectors control investors from different business sectors, including shale gas exploration and exploration investments.

The control of the General Inspectorate of Environmental Protection (IEP) is focused on environmental aspects related to exploration and production activities as well as post-production activities, e.g. water intake, sewerage, waste production and management, treatment of substances and their mixtures. The most important element of control is the assessment of the environmental impact of the installation or rig, effectiveness of solutions protecting the environment and reliability of the installation operator. After discovering violations or inconsistencies in the activity in comparison to the conditions determined in the permits, the inspectors are obliged to apply relevant sanctions, e.g. impose a fine in form of a penalty notice or, in the case of serious damage (event with participation of dangerous substances), they may present a decision obliging the violator to analyze the causes, course and effects of the damage, as well as issuing interdictions or restrictions in environmental usage or issue a decision to suspend installation usage (Skapska, 2013).

Activities linked with shale gas exploration and exploration in Poland are obliged to conform with decisions on environmental determinants, however the decision on the need to assess the environmental impact depends on the administrative organ that issues decisions on environmental determinants. According to Polish law, decisions on environmental impact are issued by various administrative organs depending on the type of investment. In shale gas activities, the decisions are issued by the regional directorate on environmental protection, district head, village head, mayor or city mayor. Decisions should be obtained also for production (Skapska, 2013; Uliasz-Misiak et al., 2014).

The impact of shale gas exploration and production and its production on Natura 2000 areas should be considered with regard to: (1) potential impact on the Natura 2000 area, and (2) the procedure of obtaining a permit for an investment with potentially negative impact on a Natura 2000 area. Assessment of the possible impact of the operation on the Natura 2000 area follows the procedure of "assessment of environmental impact" prior to the decision. Should the relevant administrative organ (e.g. issuing a building permit, permit for water usage or permit for tree felling) decide that the project requires an assessment of potential impacts on a Natura 2000 area, the proposer is obliged to initiate separate proceedings at the Regional Directorate of Environmental Protection, which decides whether full assessment of environmental impact on the Natura 2000 area is required. This assessment includes the process of public consultations. Next, the Regional Director for Environmental Protection issues a resolution with a permit for establishment of the operation. Additional conditions to be met prior to project realization may also be issued. Operations with potentially negative impacts on protected Natura 2000 areas may also by conducted using the permit of the Regional Directorate for Environmental Protection if they fulfill the criterion of public interest, including social and economic interest, with a lack of rational alternative solutions. In this case, the operator should apply a scheme of nature compensation ensuring the integrity and correct functioning of the Natura 2000 area.

It should be noted that even if there is no obligation for obtaining a decision on environmental impact, shale gas activities still require an assessment of environmental impact of the investment within a Natura 2000 area if there is a risk of serious environmental violation. In the case of a presumption that shale gas activities may potentially have significant and seriously impact on the protected area and realization of the operation is not justified, an interdiction of further shale gas activities may be issued (Rutkowska-Subocz, 2012; Pliszczyñska, 2013).

In shale gas exploration areas, the most important method of passive groundwater protection is water monitoring. Correct designing 
of a water monitoring system is based on studies allowing for early recognition of the real impact of drilling and production activities on groundwater. An optimally operating monitoring network should allow an explicit determination of the direction, range and area of water pollution, both during shale gas exploration and production (Hudak and Loaiciga, 1993). At the present stage of shale gas exploration and exploration in Poland, the problem of adequate planning and installation of a groundwater monitoring network is of crucial significance, therefore issues related to this topic should be discussed in detail.

Groundwater monitoring studies in shale gas exploration areas should refer to analysis of the water condition and quality at different times and in space. Results of systematic monitoring in Poland in various ranges should become the base for optimal systems of operational monitoring, adjusted to issues linked with potential impact of shale gas drilling. So far, Polish experience combined with study methods arising from groundwater quality control in areas of shale gas deposits in the U.S., as well as with European guidelines on water protection resulting from obligatory Directives, are the basis for present assumptions for the optimal organization of a monitoring network in regions of shale gas production (Eliasson at. al., 2003; Scott et al, 2011).

Solving specific issues linked with groundwater monitoring in hydrocarbon exploration and production areas is focused on planning and designing optimal observation systems. The systems are classified as local operational monitoring systems. There are no systematic and formal solutions or any organized supervision by public services, whereas the practical guidelines are expressed by scientific bodies (concepts, analyses, field studies) and commercial enterprises dealing with gas exploration and production (good practice rules).

\section{Active protection - examples of regulations applied in Poland}

Active groundwater protection is largely based on the application of relevant and modern technical measures. Water environment protection (i.e. of groundwater of the usable aquifer horizon) against fracturing fluid influx is focused on the preparation, transportation and storage of the fluid carried out always with the assurance of full automatic sealing. Accidental influx of the fracturing fluid components into the water environment is prevented by application of protective measures (PEHD foil) in sites of fracturing and reception and at installations for fluid cleansing. The extracted reservoir fluids and flow-back fluids are stored in containers that guarantee air tightness during storage.

Hazards for the soil-water environment include oil and fuel spills and rainwater flowing from the drilling rig. These are minimized by actions typical for all drilling activities and are generally focused on protecting the stored materials and substances by sheltering them from atmospheric influence and sealing the area beneath fuel reservoirs and containers of hazardous wastes with PEHD foil. These are standardized actions, supervised by relevant authorities (Massmann and Freeze, 1987).

Other types of active groundwater protection in shale gas exploration areas include processes of initial treatment and recycling of flow-back fluids for repeated usage in subsequent fracturing. This allows protection of water resources both with regard to quantity and quality (Mantell, 2011; Krogulec, Sawicka 2012).

\section{Groundwater monitoring networks in shale gas exploration areas}

\section{Legal provisions in the organization of groundwater monitoring systems}

Groundwater monitoring in shale gas production is controlled worldwide by legal regulations and professional guidelines. These include: (1) general state and international legal acts, (2) special legal acts linked with hydrocarbon concessions, exploration and production, and (3) good practice rules worked out and implemented by operators of monitoring networks.

Generally environmental regulations are focused on legal provisions in which there are no special instructions for assessing the potential influence of shale gas exploration and production on groundwater. However these can be applied or adapted for the assessment of the impact of shale gas exploration and production.

Special legal acts regulating groundwater monitoring in areas with shale gas production have been introduced between in 2011-2012 in several U.S. states (Table 3). They are not Federal regulations and particular states have adapted different legal constructs as well as different substantive arrangements on the extent, frequency and range of the studies. Obligatory monitoring was established only in New York and Ohio. Potential monitoring (i.e. to be undertaken after inspections) was established in Alaska and California. Another form of water monitoring, based on rebuttable presumptions, was introduced in Pennsylvania and West Virginia. A common and key constituent of all approaches is basic monitoring, i.e. recognition of groundwater quality prior to drilling activities. In many areas of intense production in the U.S. this action is hindered or practically impossible among other things, due to the ongoing mining activities (Ram, 2011; Davis, 2012; Blohm et al, 2012) .

Good practice provisions, encompassing a set of regulations and instructions for enterprises and subcontractors dealing with shale gas exploration and production, have been worked out by geological and hydrogeological surveys, scientific centers, consortia and associations. Examples of such regulations and instructions are: Guiding Principles and Operating Practices for Hydraulic Fracturing (2011) recommended by the Canadian Association of Petroleum Producers (CAPP); Shell Baseline Groundwater Sampling Program (Paulson, 2012) issued by the AECOM corporation based on regulations of institutions and organizations from Colorado; and the Code of Responsible Acquisition of Natural Gas and Crude Oil (PGNiG, 2012).

EU countries are obliged to transpose legal Directives into their national legal provisions and to implement them. The mechanism used for control of environmental impact of operations linked with shale gas exploration and production is commonly one of managing environmental risk. A report prepared for the British Government (The Royal Society, 2012) recommended the application of the Environmental Risk Assessment, (ERA) for all shale gas proposals. It proposed that companies should be obliged to restrict hazards to the lowest rationally possible level using the best available methods. An important element of environmental risk management in this case is development of models of potential pollution pathways and independent monitoring prior to, during and after activities on the drilling rigs for exploration and exploitation of shale gas (Talbot and Morris, 2012). In Germany, according to its mining act, analysis of 
Table 3. Legal acts and regulations in groundwater monitoring for areas of shale gas exploration and production (after Mutz and Kruger, 2012, modified)

\begin{tabular}{|c|c|c|c|c|}
\hline $\begin{array}{l}\text { Country/ } \\
\text { State }\end{array}$ & $\begin{array}{c}\text { Agency/ } \\
\text { Department }\end{array}$ & $\begin{array}{c}\text { Groundwater } \\
\text { sampling }\end{array}$ & Sampling procedure & Introduction date \\
\hline $\begin{array}{l}\text { USA/ } \\
\text { New York }\end{array}$ & $\begin{array}{l}\text { New York State } \\
\text { Department of } \\
\text { Environmental } \\
\text { Conservation } \\
\text { (DEC) }\end{array}$ & Required & $\begin{array}{l}\text { - sampling of all wells located at } 1000 \mathrm{ft}(305 \mathrm{~m}) \text { from } \\
\text { the pad with owner's consent, or } 2000 \mathrm{ft}(710 \mathrm{~m}) \text { if } \\
\text { well sampling is not possible due to lack of owners } \\
\text { or lack of owner's consent, } \\
\text { - first initial sampling before well drilling on the pad or } \\
\text { before drilling a subsequent well on multi-well pads, } \\
\text { - after } 3 \text { months after drilling accomplishment (till the } \\
\text { final depth) of each well, } \\
\text { - after } 3,6 \text { and } 12 \text { months after hydraulic fracturing } \\
\text { in each well. }\end{array}$ & $\begin{array}{l}\text { January } 2012 \\
\text { http://www.dec.ny.gov/docs/ } \\
\text { materials_minerals_pdf/ } \\
\text { rdsgeisch70911.pdf }\end{array}$ \\
\hline $\begin{array}{l}\text { USA/ } \\
\text { Pennsylvania }\end{array}$ & $\begin{array}{l}\text { Pennsylvania } \\
\text { Department of } \\
\text { Environmental } \\
\text { Protection, Office } \\
\text { of Oil and Gas } \\
\text { Management }\end{array}$ & $\begin{array}{l}\text { Rebuttable } \\
\text { presumption }\end{array}$ & $\begin{array}{l}\text { - party that has caused pollution or excessive use of } \\
\text { water resources (public or private) is required to } \\
\text { restore their initial state or substitute them by } \\
\text { water resources from a different source of the same } \\
\text { quality and quantity, } \\
\text { - responsibility for water pollution is incriminated } \\
\text { on the party whose drilling is located at a distance } \\
\text { of up to } 2500 \mathrm{ft}(762 \mathrm{~m} \text { ) and the pollution took } \\
\text { place within } 12 \text { months from the drilling, fracturing } \\
\text { or other activities on the drilling rig, } \\
\text { - the party is obliged for a temporal supply of potable } \\
\text { water till its resources are not restored to the relevant } \\
\text { quality and quantity state, } \\
\text { - well and source owners should be warned by the } \\
\text { party that in the case of lack of access to these } \\
\text { objects for studies (prior to drilling or other } \\
\text { activities on the drilling rig), the party cannot be } \\
\text { brought to justice in the case of later changes } \\
\text { in water state and quality. }\end{array}$ & $\begin{array}{l}\text { March } 2012 \\
\text { ttp://files.dep.state.pa.us/OilGas/ } \\
\text { hBOGM/BOGMPortal Files/ } \\
\text { OilGasReports/2012/act13.pdf }\end{array}$ \\
\hline $\begin{array}{l}\text { USA/ } \\
\text { California }\end{array}$ & $\begin{array}{l}\text { State of California } \\
\text { Department of } \\
\text { Conservation, } \\
\text { Division of Oil, } \\
\text { Gas and } \\
\text { Geothermal } \\
\text { Resources }\end{array}$ & $\begin{array}{l}\text { May be } \\
\text { required }\end{array}$ & $\begin{array}{l}\text { - inspections may recommend the party the } \mathrm{n} \\
\text { introductio of a monitoring program, planned to } \\
\text { recognize the inflow of substances derived from } \\
\text { equipment and reservoirs used in oil and gas } \\
\text { production to water and soils, }\end{array}$ & $\begin{array}{l}\text { October } 2012 \\
\text { ftp://ftp.consrv.ca.gov/pub/oil/ } \\
\text { laws/ PRC01.pdf }\end{array}$ \\
\hline $\begin{array}{l}\text { USA/ } \\
\text { North Dakota }\end{array}$ & $\begin{array}{l}\text { North Dakota } \\
\text { Industrial } \\
\text { Commission, } \\
\text { Department of } \\
\text { Mineral } \\
\text { Resources, } \\
\text { Oil and Gas } \\
\text { Division }\end{array}$ & $\begin{array}{l}\text { Not } \\
\text { required }\end{array}$ & $\begin{array}{l}\text { - owners of grounds located at a distance of half a } \\
\text { mile (c. } 805 \mathrm{~m} \text { ) from the gas production well who } \\
\text { can prove that their water intakes have been } \\
\text { affected in terms of quality and/or quantity of } \\
\text { water may take steps to obtain reimbursement } \\
\text { of repair costs, treatment or water supply in } \\
\text { volume and quality prior to the accomplishment } \\
\text { of the drilling processes. }\end{array}$ & $\begin{array}{l}2009 \\
\text { https://www.dmr.nd.gov/ } \\
\text { oilgas/rules/rulebook.pdf }\end{array}$ \\
\hline Canada & $\begin{array}{l}\text { Canadian } \\
\text { Association } \\
\text { of Petroleum } \\
\text { Producers(CAPP) }\end{array}$ & Recommended & $\begin{array}{l}\text { - companies comprising CAPP are recommended to } \\
\text { conduct monitoring determining the initial state: } \\
\text { - local - samples from intakes and sources in } \\
\text { the range of } 250 \mathrm{~m} \text { from the drilling, analyses } \\
\text { focused on comparison with existing } \\
\text { regulations on water quality (with particular } \\
\text { attention on the presence of gas in the water, } \\
\text { isotopic analyses when needed); } \\
\text { - regional - if it does not function, it is } \\
\text { recommended that the companies should start } \\
\text { cooperation with relevant administrative and } \\
\text { scientific organs in order to elaborate and } \\
\text { introduce a relevant system. }\end{array}$ & $\begin{array}{l}2011 \text { - Guiding Principles and } \\
\text { Operating Practices for } \\
\text { Hydraulic Fracturing } \\
\text { http://www.capp.ca/canadaIndustry/ } \\
\text { naturalGas/ShaleGas/Pages/ } \\
\text { default.aspx\#operating }\end{array}$ \\
\hline
\end{tabular}


environmental impact is not necessary when daily gas production for commercial purposes is below $500,000 \mathrm{~m}^{3}$ but such amounts are not obtained in the case of shale gas. According to the Federal Environmental Office, 26 applications for permits to make exploration drillings have been submitted in Lower Saxony, North Rhine Westphalia and Thuringia. Authorities of North Rhine Westphalia have demanded obligatory environmental analyses prior to exploratory and production drilling. In the case of Lower Saxony, the industrial commission has accepted the application for extended environmental analyses only in the case of production when initial studies have confirmed environmental hazard. Despite the fact that shale gas is not currently exploited in Germany, the industry has been utilizing "Frac" technology for a long time to make better use of conventional resources (Grift, 2012; Musialski et al, 2013). In France there is a moratorium on the application of hydraulic fracturing, although its revocation is being discussed (Martor, 2012; Musialski et al, 2013).

\section{Legal conditions in the organization of ground- water monitoring networks in Poland}

The following regulations in the field of groundwater monitoring are in effect in Poland:

- Regulation of the Minister of the Environment of 23 July 2008 on the criteria and methods of evaluation of groundwater (http:// isap.sejm.gov.pl/DetailsServlet?id=WDU20081430896); and

- Regulation of the Minister of the Environment of 15 November 2011 (http://isap.sejm.gov.pl/DetailsServlet?id=WDU2011 2581550) determining the form and method of monitoring of uniform parts of surface and groundwater.

Obligatory legal acts and recommendations do not take account of the characteristics of the chemical composition of technological fluids used in hydraulic fracturing and potential hazard posed on groundwater following the application of this technology.

\section{Types and functions of groundwater monitoring with regard to shale gas exploration}

Groundwater monitoring is understood as a controlling-decision system of assessing dynamics of groundwater transformations. It is a stationary, uniform and repeatable system of groundwater analysis: making measurements, preparation of assessments, and prediction of water dynamics and quality. Groundwater monitoring systems in Poland comply with the requirements for groundwater analysis in EU countries, presented in Directive 2000/60/EC. The main, superordinate aim of all types of groundwater monitoring is the protection of these waters.

Location of study sites and organization of the monitoring network in regions of shale gas exploration and production as well as the range and frequency of studies depend on the anticipated potential water hazards. But standard monitoring systems in Poland and other countries may not be the best basis for making conclusions on the impact of shale gas exploration and production on groundwater.

Location of study sites and organization of the monitoring network in regions of shale gas exploration and production as well as the range and frequency of studies depend on the anticipated potential water hazards. But standard monitoring systems in Poland and other countries may not be the best basis for making conclusions on the impact of shale gas exploration and production on groundwater.

\section{Range, area and frequency of groundwater monitoring in shale gas exploration areas}

The range of physical and chemical analyses of water is a significant element optimizing the functioning of a groundwater monitoring network in areas of shale gas exploration and production. Correct selection of parameters and chemical components is important for the unequivocal identification of pollution sources (from the activity carried out on the drilling rig) and, at the same time, for precise determination in technical and economical terms (Vrba, 1989).

Indication of optimal (with regard to the possibility of sampling, comparison of results and economical reasons) indexes of groundwater pollution requires recognition of hydrogeological and hydrogeochemical conditions for the initial state prior to drilling activities and thus prior to any sort of impact of the operation on groundwater composition. The hydrogeochemical "base-line" state should be understood as that groundwater chemical composition provides a reference level/state that will allow direct comparison and assessment of changes in water chemistry in the succeeding monitoring stages depending on the activities and treatments at the drilling rig (Paulson, 2012; Talbot and Morris, 2012; Mutz and Kruger, 2012).

The range of properties and components analyzed in water samples should be always selected to represent the pollution indicators characteristic of 1) usable groundwater of the studied area, 2) reservoir waters accompanying gas shales (including natural gases that can migrate to the surface), 3) artificial fluids used in hydraulic fracturing and flow-back fluids. It is important to make isotopic determinations after detecting significant amounts of methane in order to identify the origin of this gas to determine whether it is of bacterial or thermal origin (Schoell, 1980; Sharma and Frost 2008; Trick at. al., 2008; Goddard and Tang, 2013).

An important stage of groundwater monitoring is the assessment of the degree of pollution by determining the actual chemical state of the water (Regulation of the Minister of the Environment of 23 July 2008) and comparison with admissible concentrations of substances in usable waters intended for human consumption (Regulation of the Minister of Health of 20 April 2010).

The spatial range of studies within the monitoring network dedicated for observations of water quality in regions of shale gas exploration is the most significant element of designing a system assessing the potential impact of such operations on groundwater.

Direct implementation of the recommendations on the range of sampling from countries with a long term experience in shale gas production (U.S., Canada) is hampered in Poland by different geological conditions influencing gas production and different hydrogeological conditions characterizing groundwater reservoirs to those countries. Generally, special legal regulations or good practice recommendations restrict the range of groundwater sampling to the closest vicinity to the drilling - in the range of several tens to several hundreds of meters. Only the Canadian provisions suggest the need to include regional studies, but without elaborating on their detailed range (Table 3).

In present day environmental decisions in Poland (which result from the experience of the authors), monitoring analysis is recommended directly within the drilling rig, particularly around earth reservoirs for operational fluids as well as possible studies on a regional scale, particularly when the potential impact of the drilling encompasses hydrogeological units or natural areas that are protected 
or susceptible to pollution (Main Groundwater Reservoirs, Natura 2000 areas)

The number, type and depth of the observation points strictly depends on hydrogeological conditions (with particular consideration of groundwater filtration directions) and type and scale of exploration and later production, as well as specific spatial management (Meyer and Brill, 1988; Hudak et al, 1996). Therefore an individualized approach to the concept and project of the monitoring network is required for individual operations. The best solution for the assessment of potential impacts of the fracturing process on groundwater is a monitoring system composed of individually designed and constructed piezometers for local studies (around the drilling rig) and of the existing groundwater uptakes, sources and surface flows, forming a regional monitoring network.

The frequency of groundwater sampling chiefly depends on the type and dynamics of the exploration and production activities on the drilling rig (Zhou Y, 1996). The most important element of these monitoring studies is the multi-stage character of the observations with particular attention being drawn to the significance of the analysis and assessment of the initial hydrogeochemical state prior to exploration drilling. After each cycle of activity and treatment on the drilling rig (horizontal drillings, fracturing), the next step of monitoring analysis should be made. That requires more systematic sampling, at constant time intervals, but is justified only during constant and long-term production and after its completion for assessing the correct close-down of the well and successful remediation. The dedicated monitoring system is based on sampling of the entire operation from the initial stage (prior to the activities) to remediation of the area after closing-down of the drilling.

\section{Examples of groundwater monitoring systems in Poland}

In Poland, shale gas exploration activities are carried out since about 2010. In northern Poland (Pomerania region) there are individual groundwater monitoring systems for specific exploration activities (Krogulec and Sawicka, 2012). The system discussed below, in general outline, was adopted due to ongoing coordination related to subsequent exploration areas, including protests of environmental action groups. One aspect brought up in relation to the monitoring studies is their financing. Broad scientific programs, the range of which is related to the study area, are joint platforms of science and industry, financed from public and investment funds. In Poland, such investigations are not possible without investment funding for the assessment of possible groundwater sampling in the vicinity of the well and sampling of fracturing and flow-back fluids. Activities of key scientific centers guarantee neutrality of opinions and objective results of analyses.

The designed, dedicated monitoring system is a local network comprising nearby drilled wells (Fig. 2), water sources and surface flows as well as piezometers of the regional monitoring network (Fig. 3).
The first stage of activities prior to organization of groundwater monitoring was defining the risk and hazard posed by the exploration works. After defining the risk, the potential hazard posed on groundwater was determined solely with regard to the activities within the drilling pad.

The crucial element in designing a monitoring system was the recognition of hydrogeological and hydrogeochemical conditions for the initial state, prior to the beginning of the drilling activities. The hydrogeochemical initial state is understood as the chemical composition of groundwater that will become a reference level and allow direct comparison and assessment of changes in water chemical composition in subsequent monitoring stages depending on the activities and treatments within the drilling rig. Identification of hydrodynamic conditions in the usable aquifer horizons allow the determination of directions of groundwater filtration. Selecting groundwater sampling sites in relation to the recognized water filtration directions allow sampling of water below and on the drilling site (in line with the groundwater flow). The local network designed for shale gas exploration drilling comprises 6 drilled wells used for local supply in water, 2 springs and 2 surface water sampling sites that are in hydraulic contact with groundwater, 18 piezometers designed within the drilling pad, of which 12 are shallow piezometers intended to monitor potential pollution migration from reservoirs of technological fluids and 6 are piezometers placed to the depth of the usable aquifer horizon. These devices are located at a distance of c. $2-3 \mathrm{~km}$ from the drilling rig. Monitoring studies began with determining the hydrogeochemical initial state based on sampling and analysis of available archival data. Subsequent steps of the monitoring studies are underway, in accordance with the activities on the drilling pad. The drilling was already subject to hydraulic fracturing, horizontal drilling and repeated hydraulic fracturing (stage IV according to Table 4). In all monitoring steps, field studies and laboratory sampling were conducted in the range presented in Table 4 , excluding isotopic analyses, for which so far, no need was foreseen. Also, concentrations of organic substances and specific components of the artificial fluids were broadly analyzed, after each fracturing, by modifying the range of analyses depending on the composition of

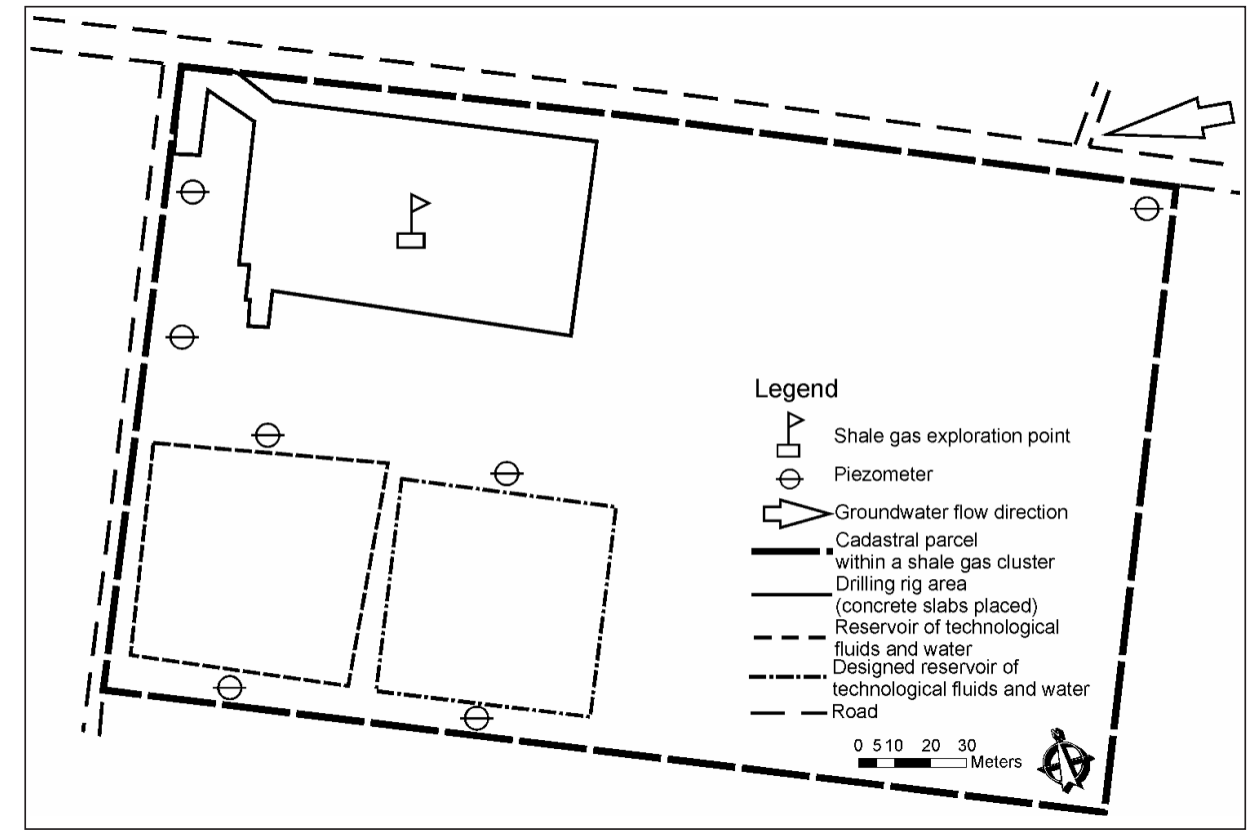

Figure 2 Local monitoring of groundwater in the area of shale gas exploration drilling 


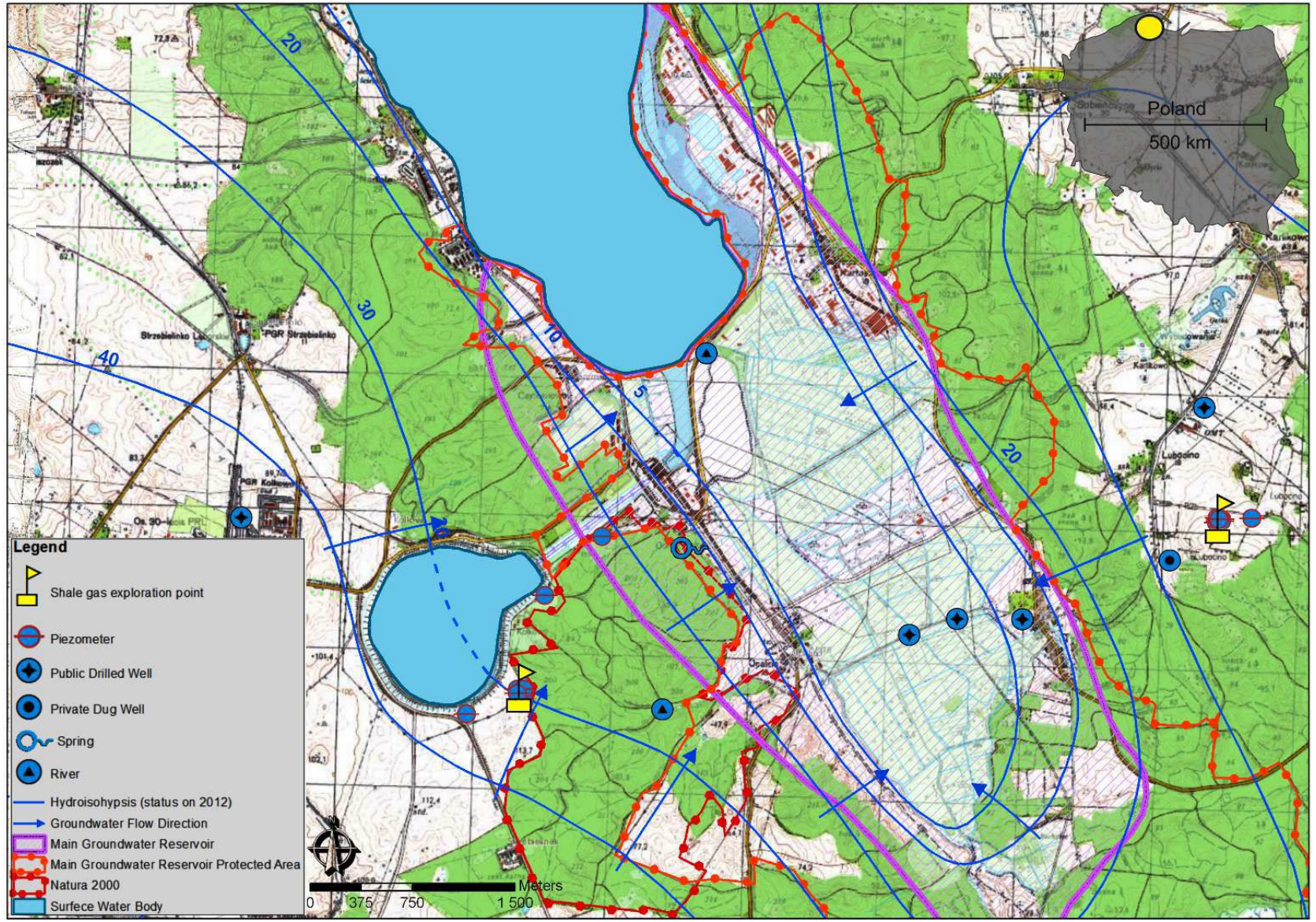

Figure 3 Regional monitoring of groundwater in the area of shale gas exploration drilling

Table 4. Groundwater monitoring in shale gas exploration and production area

\begin{tabular}{|c|c|c|c|}
\hline \multicolumn{2}{|c|}{ Range } & \multirow{2}{*}{ Frequency } & \multirow{2}{*}{ The scope of testing and sampling } \\
\hline Local & Regional & & \\
\hline \multirow{9}{*}{$\begin{array}{l}\text { Direct vicinity of the well } \\
\text { and containers for } \\
\text { technological fluid and } \\
\text { water (tens - hundreds of } \\
\text { meters) - fig. } 2\end{array}$} & \multirow{9}{*}{$\begin{array}{l}\text { Depending on the regional } \\
\text { hydrogeological conditions } \\
\text { and the units and structures } \\
\text { are particularly vulnerable } \\
\text { to the effects of the bore- } \\
\text { hole (a few miles) - fig. } 3\end{array}$} & \multirow{3}{*}{ Stage I. Base case } & Indicators/markers characteristic of: \\
\hline & & & groundwater utility \\
\hline & & & reservoir water \\
\hline & & \multirow{2}{*}{$\begin{array}{l}\text { Stage II. After completion } \\
\text { of drilling }\end{array}$} & $\begin{array}{l}\text { liquid for the treatment of hydraulic } \\
\text { fracturing }\end{array}$ \\
\hline & & & $\begin{array}{l}\text { Research the ingredients and physico- } \\
\text { chemical properties: }\end{array}$ \\
\hline & & $\begin{array}{l}\text { Stage III. After the hydraulic } \\
\text { fracturing }\end{array}$ & $\begin{array}{l}\text { Field: temperature, } \mathrm{pH}, \mathrm{PEW}, \mathrm{Eh}, \mathrm{NO}_{3}^{-} \text {, } \\
\mathrm{NO}_{2}^{-}, \mathrm{NH}_{4}^{+}, \mathrm{S}^{-} \text {, iron }\end{array}$ \\
\hline & & $\begin{array}{l}\text { Stage IV. After each successive } \\
\text { treatment or work on the pad }\end{array}$ & \multirow{3}{*}{$\begin{array}{l}\text { Laboratory: general ( mineralization, } \\
\text { hardness, alkalinity etc.), ions, metals, } \\
\text { organic, BTEX, WWA, gases, isotopic, } \\
\text { another }\end{array}$} \\
\hline & & Stage. V. During production & \\
\hline & & $\begin{array}{l}\text { Stage. VI. After completion of } \\
\text { the extraction and elimination } \\
\text { of hole }\end{array}$ & \\
\hline
\end{tabular}


the fracturing fluid and the flow-back fluid (Krogulec and Sawicka, 2013).Isotopic determinations are recommended only after methane is detected in groundwater or soil in order to identify the origin of this gas. In subsequent monitoring steps, when values of the pollution indicators are higher than in the initial state (or previous monitoring stage), it will becomes necessary to identify the source of pollution by broadening the monitoring range and determining possible directions and the range of pollution migration. The range of investigations and the proposed general range (Table 4) consists of indicators characteristic of the potential pollutants resulting from shale gas exploration and production.

The next step comprised hydrogeochemical modeling of changes in the composition of the fracturing fluid. Models simulating the 'postfracturing state' (i.e. modeling the possible changes of the flow-back fluid and the 'predicted state') allow the preparation of possible scenarios of events (Krogulec, Sawicka, 2012). The results of modeling analyses should become an important element of the organization of monitoring analyses, requiring broader studies. Both Polish and foreign experience has proved their feasibility (e.g. Xu et al, 2007; Krogulec and Sawicka, 2012; Zheng et al, 2013). Modeling methods may be utilized directly in planning the range of chemical studies in the designed monitoring program. Additionally, they allow assessment of the directions in which changes of the flow-back fluid will proceed after fracturing and of their potential impact on the environment.

Results of previous monitoring studies in the analyzed operation did not indicate the direct impact and negative influence on the chemical composition of usable groundwater. In the present stage of the activities on the drilling rig (exploration and exploration stage), significant changes in the hydrogeochemical environment of the local and regional uptakes have not been observed.

\section{Summary and conclusions}

Because of a lack of domestic experience with regard to application of hydraulic fracturing and full recognition of this technology on the environment, intense activities of shale gas exploration in Poland are at present a topic of great interest and concern to many parties, e.g.: representatives of social, economic, political and scientific institutions.

In the scientific community, hydrogeologists play a significant role in recognizing and documenting real environmental hazards in regions of shale gas exploration and production and are the specialists best equipped for the assessment, prediction and design of solutions protecting groundwater resources. These resources are significant in the technology of shale gas stimulation and production and are at the same time most susceptible to its negative impacts.

Quantitative and qualitative groundwater protection in Poland is realized using legal-administrative and technical tools (active and passive protection). The most important method of passive groundwater protection in regions of shale gas exploration is monitoring. Systematic monitoring carried out in Poland at various scales is the basis for designing optimal operational monitoring systems, specifically adapted for assessment of potential problems and impacts of shale gas drilling activities. Correctly designed monitoring networks allow early recognition of the actual impact of shale gas drilling and production activities on groundwater. An optimally operating monitoring network should allow for clear determination of the direction, range and area of potential pollution of the water environment, both at the exploration stage as well as later during shale gas production.

In Poland, and other countries, the existing solutions and legal regulations related to water monitoring are generalized and, usually, are not specifically aimed at assessment of hazards associated with shale gas exploration and production. Regulations in the existing legal acts and recommendations often do not include the characteristics of the chemical composition of fluids used for hydraulic fracturing and potential hazards to groundwater linked with the application of this technology. Therefore, there is a need for an individual approach to the concept and design of the monitoring network, in each case dedicated for a particular operation.

Assessment of the potential impact of hydraulic fracturing on groundwater is best solved by a monitoring system comprised of specially designed and constructed piezometers for local investigations (around the drilling rig) taking account of existing groundwater abstraction, springs and surface water within the regional monitoring network. The example presented here of a monitoring system for shale gas exploration and exploration in northern Poland (Pomerania) fulfills all these requirements. It was designed and implemented in 2011 and the results of the investigations indicate lack of changes in the hydrogeochemical environment in comparison to the initial state. Therefore it can be assumed that shale gas exploration activities in this region have so far not caused any negative impact on usable groundwater. The number, type and depth of the observation sites depends strictly on the hydrogeological conditions (with particular attention on groundwater filtration directions), method and scale of the exploration works and later production, as well as specific spatial management. Identification of optimal (with regard to the possibility of sampling, comparison of results and economical reasons) pollution parameters analyzed in groundwater samples requires recognition of hydrogeological and hydrogeochemical conditions. The range of these should be selected to ensure representativeness for usable groundwater in a given area, resource waters accompanying gas shales (including natural gas that can migrate to the surface) as well as the fluids used in hydraulic fracturing and flow-back fluids. The essence of an optimal monitoring system is a correctly selected frequency of the analyses. In areas of shale gas exploration and production, observations should be made in several steps, with particular emphasis on the significance of investigations and assessment of the hydrogeochemical initial state, prior to exploration drilling. After each cycle of activities and treatments in the drilling pad (horizontal drillings, hydraulic fracturing), a subsequent stage of monitoring analyses should be undertaken.

Methods of hydrogeochemical modeling may be directly utilized in planning the range of chemical analyses in the designed monitoring; moreover, they allow determination of the ways in which the chemical composition of the flow-back fluid will change after fracturing, as well as the potential impact on the environment, including the effect of potential mixing of the fracturing fluid and the flow-back fluid with usable groundwater. Additionally, modeling simulations are useful in working out technologies of flow-back recycling for subsequent fracturing treatments.

\section{References}

AEA, 2012. Support to the Identification of Potential Risks for the Environment and Human Health Arising from Hydrocarbons Operations Involving Hydraulic Fracturing in Europe. European Commission DG Environment, Brussels, p. 292, http://ec.europa.eu/environment/ 
integration/energy/pdf/fracking\%20study.pdf (accessed in May 2013).

ALL Consulting Home Page, 2010. http://www.all-1lc.com/projects/ produced_water_tool/page.php?11

Alvarez, R.A., Pacala, S.W., Winebrake, J.J., Chameides, W.L., Hamburg, S.P., 2012. Greater focus needed on methane leakage from natural gas infrastructure. Proceedings of the National Academy of Sciences , v. 109, pp.6435-6440.

Assessment of Shale Gas and Shale Oil Resources of the Lower Paleozoic Baltic-Podlasie-Lublin Basin in Poland, 2012. First Report. Polish Geological Institute-National Research Institute, (in Polish), http:// www.pgi.gov.pl/en/mineral-resources-en/shale-gas/4744-shale-gasestimates.html (accessed in May 2013).

Association of Petroleum Producers (CAPP), 2011. Guiding Principles and Operating Practices for Hydraulic Fracturing, adres: http://www.capp.ca/ canada Industry/naturalGas/Shale Gas/Pages/default.aspx\#operating (accessed in June 2013).

Blohm, A., Peichel, J., Smith, C., Kougentakis, A., 2012. The significance of regulation and land use patterns on natural gas resource estimates in the Marcellus shale. Energy Policy, v. 50, pp. 358-369.

Davis, C., 2012. The politics of Fracking: regulating natural gas drilling practices in Colorado and Texas. Review of Policy Research, v. 29, pp. 177-191.

Diagnosis of the current condition of water management. Annex 1 to Draft State Water Policy up to 2030 (Taking into Account Stage 2016), 2010. National Water Economy Board, Warsaw, (in Polish), http://kzgw.gov.pl/ pl/Projekt-Polityki-wodnej-panstwa-do-roku-2030.html (accessed in May 2013).

Eaton, T.T., 2013. Science-based decision-making on complex issues: Marcellus shale gas hydrofracking and New York City water supply. Science of the Total Environment, Volumes 461-462, pp. 158-169.

EIA 2011. World shale gas resources: an initial assessment of 14 regions outside the United States. U.S. Energy Information Administration, Washington, p. 365 http://www.eia.gov/analysis/studies/worldshalegas (accessed in June 2013).

Eliasson, A., Rinaldi, F.M., Linde, N., 2003. Multicriteria decision aid in supporting decisions related to groundwater protection. Environ Manage 32(5): 589-601. Energy Policy 53, 389-399.

Energy Policy of Poland until 2030. Ministry of Economy. Appendix to Resolution no. 202/2009 of the Council of Ministers of 10 November 2009, (in Polish) http://www.mg.gov.pl/files/upload/8134/Polityka\%20 energetyczna\%20ost_en.pdf (accessed in May 2013).

Environmental Aspects of Hydraulic Fracturing Treatment Performed on the £ebieñ LE2H Well, 2011. Final Report Polish Geological InstituteNational Research Institute, (in Polish) http://www.pgi.gov.pl/en/allevents/4087-environmental-impact-hydraulic-fracturing-lebien.html (accessed in May 2013).

Gautier, D.L., Pitman, J.K., Charpentier, R.R., Cook, T., Klett, T.R. and Shenk, C.J., 2012. Potential for technically recoverable unconventional gas and oil resources in the Polish-Ukrainian Foredeep, Poland, 2012. U.S. Geological Survey Fact Sheet 2012-3102, p. 2

http://pubs.usgs.gov/fs/2012/3102 (accessed in August 2013).

Goddard, W.A. and Tang, Y., 2013. Novel Gas Isotope Interpretation Tools to Optimize Gas Shale Production. Final Report, p. 90. http://www.netl.doe .gov/technologies/oil-gas/publications/EPact/08122-15-final-report.pdf (accessed in June 2013).

Górecki, W., 2003. Perspectives of development of the oil and gas mining in Poland. Wiadomoœci Naftowe i Gazownicze 6, no 9, 3-8 (in Polish with English abstract)

Grift, L., 2012. Germany: Legal aspects of shale gas exploration and extraction, http://www. shale-gas-information-platform.org/pl/categories/legislation/ expert-articles/ludwig-article.html (accessed in June 2013).

Ground Water Protection Council (GWPC), 2009. State Oil and Natural Gas Regulations Designed to Protect Water Resources Prepared for the U.S. Department of Energy, National Energy Technology Laboratory, http:// www.gwpc.org/elibrary/documents/general/State\%20Oil\%20and $\% 20 \mathrm{Gas} \% 20$ Regulations $\% 20$ Designed $\% 20$ to $\% 20$ Protect $\% 20$ Water\%20Resources.pdf (accessed in June 2013).

Guiding Principles and Operating Practices for Hydraulic Fracturing, 2011.
http://www.slideshare.net/MarcellusDN/capp-guiding-principles-forhydraulic-fracturing

Hammer, R., and van Briesen, J., 2012. In Fracking's Wake: New Rules are Needed to Protect Our Health and Environment from Contaminated Wastewater, NRDC Issue Brief. Natural Resources Defense Council, Washington, DC, p 9. http://www.nrdc.org/energy/files/Fracking-Waste water-IssueBrief.pdf (accessed in May 2013).

Hudak, P.F and Loaiciga, H.A., 1993. An optimization approach for monitoring network design in multilayered groundwater flow systems. Water Resources Research, v. 29 (8), pp. 2835-2845.

Hudak, P.F., Loaiciga, H.A and Marino, M.A., 1996. Regional-scale ground water quality monitoring via integer programming. Journal of Hydrology v. 164 , pp. $153-170$

Jackson, R., Rainey Pearson, B., Osborn, S.G., Warner, N.R and Vengosh, A., 2011. Research and Policy Recommendations for Hydraulic Fracturing and Shale Gas Extraction. Center on Global Change, Duke University, Durham, NC, p. 11, http://www.nicholas.duke.edu/cgc/Hydraulic FracturingWhitepaper2011.pdf (accessed in May 2013).

Jackson, R.E., Gorody, A.W., Mayer, B., Roy, J.W., Ryan, M.C and Van Stempvoort D.R., 2013. Groundwater protection and unconventional gas extraction: the critical need for field-based hydrogeological research. Ground Water, v. 51(4), pp. 488-510.

Jenner, S. and Lamadrid, A.J., 2013. Shale gas vs. coal: Policy implications from environmental impact comparisons of shale gas, conventional gas, and coal on air, water, and land in the United States. Energy Policy, v. 53 , pp. $442-453$.

Johnson, C. and Boersma, T., 2013. Energy (in)security in Poland the case of shale gas. Energy Policy, v. 53, pp. 389-399.

Kiersznowski, H. and Dyrka, I., 2013. Ordovician-Silurian shale gas resources potential in Poland: evaluation of Gas Resources Assessment Reports published to date and expected improvements for 2014 forthcoming Assessment. Przeglad Geologiczny, v. 61, no. 11/1, pp. 639-656.

Koziel, A., 2010. Current status of concessions and mining uses for recognition and documentation of unconventional natural gas deposits in Poland ("Shale Gas" and "Tight Gas"). Polityka Energetyczna, v. 13 (2), pp. 265-280 (in Polish with English abstract).

Krogulec, E.and Sawicka, K., 2012. Model analysis of chemistry transformation of the technological fluids used in obtaining gas from shale (shale gas). Biuletyn Pañstwowego Instytutu Geologicznego, no. 451, pp.161-168 (in Polish with English abstract).

Krogulec, E. and Sawicka, K, 2013. Groundwater monitoring network in the areas of exploration and availability of hydrocarbon deposits from shale formations). Biuletyn Pañstwowego Instytutu Geologicznego, no. 451, pp. 161-168 (in Polish with English abstract).

Lipiñska, E., J., 2010. Places of natural flow of oil and natural gas emissions in Podkarpacie. Infrastructure and ecology of rural areas 1/2010, 13-24, (in Polish with English abstract).

Mantell, M. E., 2011. Produced water reuse and recycling challenges and opportunities across major shale plays. In: Proceedings of the Technical Workshops for the Hydraulic Fracturing Study: Water Resources Management. EPA 600/R-11/048, May 2011, 49-57, http://www2.epa. gov/sites/production/files/documents/HF_Workshop_4_Proceedings_ FINAL 508.pdf (accessed in June 2013).

Martor, B, 2012. France: Evolutions in the legal framework for shale oil and gas http://www.shale-gas-information-platform.org/pl/categories/ legislation/expert-articles/martor-article.html (accessed in May 2013).

Massmann, J.and Freeze, R.A., 1987. Groundwater contamination from waste management sites: the interaction between risk-based engineering design and regulatory policy, 1, Methodology. Water Resources Research, v. 23 (2), pp. 351-367.

Meyer, P.D.and Brill, E.D., 1988. Method for locating wells in a ground water monitoring network under conditions of uncertainty. Water Resources Research, v. 24 (8), pp.1277-1282.

Musialski, C., Zittel W., Lechtenbohmer, S., Altman, M., 2013. Shale gas in Europe. Opportunities, risks, challenges: a multidisciplinary analysis with a focus on europeans specifities. European Energy Studies, vol. V. Claeys \& Casteels, p. 350.

Mutz, K. and Kruger, J., 2012. Monitoring and Protecting Groundwater During 
Oil and Gas Development: Survey of State Sampling and Monitoring Rules. Monitoring and Protecting Groundwater During Oil and Gas Development Workshops. University of Colorado Law School, November 26, 2012, http://www.oilandgasbmps.org/workshops/COGCCground water/presentations/Mutz2.pdf (accessed in June 2013).

Paulson, J., 2012. AECOM/Shell Baseline Groundwater Sampling Program. http://www.hughescollaboration.com/app/download/6810937404/ AECOM+water+well+testing+15-Mar-2012.pdf (accessed in July 2013).

Parkhurst, D.L.and Appelo, C.A.J., 1999. User's guide to PHREEQC (version 2) - A computer program for speciation, batch-reaction, one-dimensional transport, and inverse geochemical calculations: U.S. Geological Survey Water-Resources Investigations Report 99-4259, p. 312.

Pliszczyñska K., 2013. Prospection and exploration of unconventional hydrocarbon deposits - progress in work and actions of the Ministry of the Environment.. Przegl'1 ${ }^{1}$ Geologiczny 61, no 6, 334-337 (in Polish with English abstract).

PGNiG. Polskie Górnictwo Naftowe i Gazownictwo (), 2012. Code of Responsible Acquisition of Natural Gas and Crude Oil, p. 5. http:// www.pgnig.pl/binsource doc $\mathrm{Id}=49838$ \&language $=$ PL \& paramName $=$ BINARYOBJ_FILE\&index=0 (accessed in June 2013).

Rahm, B.G. and Riha S.J., 2012. Toward strategic management of shale gas development: regional, collective impacts on water resources. Environmental Science Policy, v.17, pp. 12-23.

Ram, D., 2011. Regulating hydraulic fracturing in shale gas plays: The case of Texas. Energy Policy, v. 39, pp. 2974-2981.

Rutkowska-Subocz, E., 2012. Poland: Legal aspects of shale gas exploration and production http://www.shale-gas-information-platform.org/pl/ categories/legislation/expert-articles/rutkowska-article-polnisch.html (accessed in June 2013).

Sakmar, S. L., 2012. Overview of Environmental Issues and US Regulatory Framework Pertaining to US Shale Gas Development http://www.shalegas-information-platform.or $\mathrm{g} / \mathrm{pl} /$ categories/legislation/expert-articles/ sakmar-article.html (accessed in July 2013).

Scott, C.A., Pierce, S.A., Pasqualetti, M.J., Jones, A.L., Montz, B.E., Hoover, J.H., 2011. Policy and institutional dimensions of the water-energy nexus. Energy Policy, v. 39, pp. 6622-6630.

Schoell, M., 1980. The hydrogen and carbon isotopic composition of methane from natural gases of various origins. Geochim Cosmochi Acta, v. 44, pp. 649-661.

Sharma, S.and Frost C.D., 2008. Tracing coalbed natural gas-coproduced water using stable isotopes of carbon. Ground Water, v. 46, pp. 329-334.

Skapska, A., 2013. Actions of the Inspection of Environmental Protection bodies as regards control of activities related to shale gas prospection. Przeglad Geologiczny 61, no 6, 343-346 (in Polish with English abstract).

Talbot, S. and Morris, P, 2012. UK Shale gas - the role of baseline and operational continuos ground-gas monitoring. Integrated Petroleum Environmental Consortium (IPEC) 19th Conference, p. 12 http:// ipec.utulsa.edu/Conf2012/PapersPresentations /Morris_Manuscript.pdf (accessed in June 2013).

The Royal Society and The Royal Academy of Engineering, 2012. Shale Gas Extraction in the UK: A Review of Hydraulic Fracturing, London, p 76. http://www.raeng.org.uk/news/publications/list/reports/Shale_Gas.pdf (accessed in May 2013).

Trick, J.K., Stuart, M.and Reeder, S., 2008. Chapter 3: Contaminated Groundwater Sampling and Quality Control of Water Analyses [in:] Environmental Geochemistry by De Vivo B., Belkin H.E., Lima A., Amsterdam, 29-57 (429).

Uliasz-Misiak, B., Winid B., 2012. Production of Hydrocarbons and Protected Areas in Poland. Rocznik Ochrona Srodowiska, 14, 919-929 (in Polish with English abstract).

Uliasz-Misiak, B., Andrzej Przybycin A., Bogumila Winid B., 2014. Shale and tight gas in Poland - legal and environmental issues. Energy Policy, v. 65 , pp. 68-77.

US Environmental Protection Agency, 2010. Scoping Materials for Initial Design of EPA Research Study on Potential Relationships Between Hydraulic Fracturing and Drinking Water Resources. EPA Office of Research and Development, Washington, DC, p. 12 http://yosemite. epa.gov/sab/SABPRODUCT.NSF/0/3B745430D624ED3B852576
D400514B76/\$File/Hydraulic+Frac+Scoping+Doc+for+SAB-3-2210+Final.pdf (accessed in May 2013).

US Environmental Protection Agency, 2011. Plan to Study the Potential Impacts of Hydraulic Fracturing on Drinking Water Resources. EPA Office of Research and Development, Washington DC, p. 190.

http://water.epa.gov/type/groundwater/uic/class2/hydraulicfracturing/upload/ hf_study_plan_110211_final_508.pdf (accessed in June 2013)

US Environmental Protection Agency, 2012. Study of the Potential Impacts of Hydraulic Fracturing on Drinking Water Resources Progress Report. EPA Office of Research and Development, Washington DC, p. 262. http: //www2.epa.gov/sites/production/files/documents/hf-report20121214.pdf (accessed in June 2013).

Vengosha, A., Warnera, N., Jackson, R., Darraha, T., 2013. The effects of shale gas exploration and hydraulic fracturing on the quality of water resources in the United States. Procedia Earth and Planetary Science, v. 7, pp. $863-866$.

Vrba, J., 1989. Economic Aspects of Groundwater Protection. Developments in Water Science, v. 39, pp. 153-180.

Xu, T., Apps, J.A., Pruess, K., Yamamoto, H., 2007. Numerical modeling of injection and mineral trapping of $\mathrm{CO}_{2}$ with $\mathrm{H} 2 \mathrm{~S}$ and $\mathrm{SO}_{2}$ in a sandstone formation. Chemical Geology, v. 242, pp. 319-346.

Zagórski, J., 2013. Aktualia ropy naftowej i gazu ziemnego. Przeglad Geologiczny 61, no 3, 162-164 (in Polish with English abstract).

Zheng, L., Spycher, N., Birkholzer, J., XU T., Apps, J., Kharaka, Y., 2013. On modeling the potential impacts of $\mathrm{CO}_{2}$ sequestration on shallow groundwater: Transport of organics and co-injected $\mathrm{H}_{2} \mathrm{~S}$ by supercritical $\mathrm{CO}_{2}$ to shallow aquifers. International Journal of Greenhouse Gas Control v. 14, pp. 113-127.

Zhou, Y., 1996. Sampling frequency for monitoring the actual state of groundwater systems. Journal of Hydrology, v. 180, pp. 301-318.

\section{Legal documents}

Regulation of the Minister of the Environment of 23 July 2008 (Dz. U. 2008 $\mathrm{Nr}$ 143, poz. 896). http://isap.sejm.gov.pl/DetailsServlet?id=WDU2008 1430896

Regulation of the Minister of the Environment of 11 November 2011 (Dz.U. $2011 \mathrm{nr} 258$ poz. 1550). http://isap.sejm.gov.pl/DetailsServlet?id=WDU 20112581550

Water Law (Dz.U. 2001 nr 115 poz. 1229). http://isap.sejm.gov.pl/Details Servlet?id=WDU20011151229

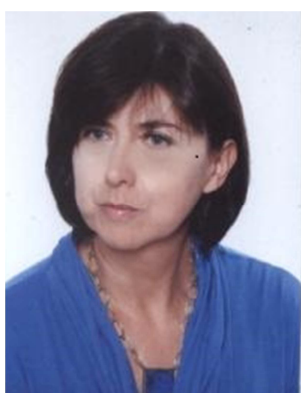

Ewa Krogulec is a Professor of Warsaw University and Dean of Geology Faculty and Head of the Department of Groundwater Hydrogeochemistry and Groundwater Dynamics. She specialises in the groundwater protection studies in urban, mining, and protected areas and participates in many domestic and international scientific projects which focus on the different aspects of hydrogeological research methodology.

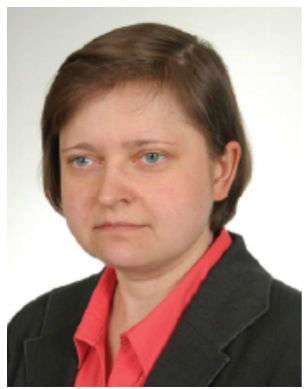

Katarzyna Sawicka, is an Assistant Professor in the Geology Faculty of Warsaw University doing research and teaching about hydraulic and hydrologic engineering, hydrogeology and groundwater chemistry. Her research interests include analyzing natural and human-impacted hydrogeologic systems, groundwater management and protection, geochemistry and groundwater contamination caused by agricultural and industrial activities. 